\title{
"State regulation of sustainable innovation project funding in the EU countries and Ukraine"
}

\begin{tabular}{|c|c|}
\hline AUTHORS & $\begin{array}{l}\text { Viktor Oharenko (D) } \\
\text { R } \\
\text { Anzhela Merzlyak (D) } \\
\mathbb{R} \\
\text { Viktoriia Tomareva-Patlakhova (D) } \\
\mathbb{R} \\
\text { luliia Vikhort (D) } \\
\mathbb{R} \\
\text { Daria Skriabina (D) } \\
\mathbb{R}\end{array}$ \\
\hline ARTICLE INFO & $\begin{array}{l}\text { Viktor Oharenko, Anzhela Merzlyak, Viktoriia Tomareva-Patlakhova, luliia Vikhort } \\
\text { and Daria Skriabina (2021). State regulation of sustainable innovation project } \\
\text { funding in the EU countries and Ukraine. Investment Management and Financial } \\
\text { Innovations, } 18(2), 374-390 \text {. doi:10.21511/imfi.18(2).2021.30 }\end{array}$ \\
\hline DOI & http://dx.doi.org/10.21511/imfi.18(2).2021.30 \\
\hline RELEASED ON & Tuesday, 29 June 2021 \\
\hline RECEIVED ON & Friday, 28 May 2021 \\
\hline ACCEPTED ON & Friday, 25 June 2021 \\
\hline LICENSE & $\begin{array}{l}(c) E Y \text { EY } \\
\text { This work is licensed under a Creative Commons Attribution } 4.0 \text { International } \\
\text { License }\end{array}$ \\
\hline JOURNAL & "Investment Management and Financial Innovations" \\
\hline ISSN PRINT & $1810-4967$ \\
\hline ISSN ONLINE & $1812-9358$ \\
\hline PUBLISHER & LLC “Consulting Publishing Company "Business Perspectives" \\
\hline FOUNDER & LLC "Consulting Publishing Company "Business Perspectives" \\
\hline
\end{tabular}

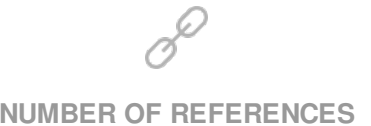

38

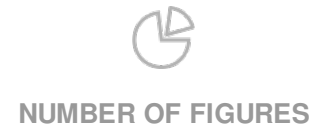

9
NUMBER OF TABLES

3

(C) The author(s) 2021. This publication is an open access article. 


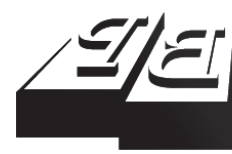

\section{BUSINESS PERSPECTIVES}

-

LLC "CPC "Business Perspectives"

Hryhorii Skovoroda lane, 10,

Sumy, 40022, Ukraine

www.businessperspectives.org
Received on: $28^{\text {th }}$ of May, 2021 Accepted on: $25^{\text {th }}$ of June, 2021 Published on: $29^{\text {th }}$ of June, 2021

(C) Viktor Oharenko, Anzhela Merzlyak, Viktoriia Tomareva-Patlakhova, Iuliia Vikhort, Daria Skriabina, 2021

Viktor Oharenko, Doctor of Public Administration, Professor, Professor of the Public Administration and Land Management Department, Rector of Classic Private University, Public Administration and Land Management Department, Management Institute, Classic Private University, Ukraine.

Anzhela Merzlyak, Doctor of Public Administration, Professor, Professor of the Management Department, Director of Management Institute, Management Department, Management Institute, Classic Private University, Ukraine.

Viktoriia Tomareva-Patlakhova, Doctor of Economics, Associated Professor, Head of the Management Department Management Institute, Classic Private University, Ukraine.

Iuliia Vikhort, Ph.D. in Economics, Associated Professor, Associated Professor of the Management Department, Management Institute, Classic Private University, Ukraine. (Corresponding author)

Daria Skriabina, Ph.D. in Public Administration, Associated Professor, Associated Professor of the Management Department, Management Institute, Classic Private University, Ukraine.

This is an Open Access article, distributed under the terms of the Creative Commons Attribution 4.0 International license, which permits unrestricted re-use, distribution, and reproduction in any medium, provided the original work is properly cited.

Conflict of interest statement: Author(s) reported no conflict of interest
Viktor Oharenko (Ukraine), Anzhela Merzlyak (Ukraine),

Viktoriia Tomareva-Patlakhova (Ukraine), Iuliia Vikhort (Ukraine),

Daria Skriabina (Ukraine)

STATE REGULATION

OF SUSTAINABLE INNOVATION
PROJECT FUNDING IN THE EU
COUNTRIES AND UKRAINE

\begin{abstract}
The effective implementation of innovations is broadly determined by the ways of their financing, among which project funding is particularly important today. This paper examines the impact of project funding on the innovative growth of the state in the EU countries and Ukraine in the context of sustainable development. Using theoretical and empirical methods, this study identifies and systematizes traditional and innovative forms of sustainable innovation project funding, which are practically used by the EU member states and Ukraine. Based on statistical methods, data analysis for the period from 2014 to 2020 and indicators characterizing the participation of countries in the largest European project funding program Horizon 2020 and other similar programs, the study revealed a close relationship between the conditions created by the state for participation in project funding programs and indicators of innovation activity and the climate of the state. The study allowed determining that funding from international sources, including funds from leading European institutions, which support the dissemination of sustainable innovations, can be a good alternative for innovation project funding under limited domestic resources. The study concluded that diversification of sources and forms of project funding, use and support from the state influences and accelerates the development of innovation infrastructure in a country (clusters, business incubators etc.), as well as the interaction between various participants in a sustainable innovation process (state, regions, large enterprises, small and medium-sized businesses, communities).
\end{abstract}

Keywords

project funding, project, innovation, sustainable development, international grant funding, domestic investment funding, credit funding, public regulation, EU countries, Ukraine

JEL Classification G28, G23, O38

\section{INTRODUCTION}

Over the past decades, the project approach has become a key factor for successful implementation of development programs in different areas. This approach began to be actively used at the beginning of the $21^{\text {st }}$ century, although until now it has been used by large multinational companies such as Boeing, Hewlett Packard, IBM, Intel, Volkswagen, etc., as well as by some individuals or associations of citizens, mostly due to grant funds raised from international organizations and foundations.

The project approach has gained significant relevance in the field of innovation activity and, meanwhile, sustainable innovation is no exception. This issue was considerably boosted in the world by the adoption of Sustainable Development Goals at the UN Summit on Sustainable Development in September 2015 (in force until 2030). Until this time, the EU development strategy (Europe - 2020), was based on smart, sustainable and inclusive growth. And the relevant issues of sustainable production and consumption, efficient use of natural resources, waste 
minimization and pollution prevention, increasing resource efficiency, design of business models based on environmentally friendly technologies, close interaction between environmental, social and economic components are currently a priority.

Governments around the world use a variety of methods to finance innovation, improve innovation infrastructure in a country and ensure the sustainable development vector, but post-industrial countries, and Ukraine is among them, often face the lack of direct state funding, so it is very important to attract additional funds by different participants of innovation process from diversified sources. And just project funding can serve as an instrument that provides interests of all stakeholders and ensures targeted use of raised funds for definite purposes.

Nowadays, the practice of project funding in Ukraine, compared to EU countries, is not widespread enough. Thus, financing of projects, especially related to sustainable innovations, is provided only by a small number of banks, which within this type of funding offer loans mainly for commercial real estate construction projects. Funding of large-scale projects and programs covers only certain strategic areas of the national household and is provided by the state, local communities. Unfortunately, this process is slowed down by shortage of funds in state and local budgets, unestablished mechanism of such interaction, and lack of sufficient experience in project funding. The activity of enterprises, individuals, educational and scientific organizations within the framework of participation in grant programs remains rather low. Funding of projects by private investors is limited by imperfect conditions of doing business in the state, unstable regulatory framework, high uncertainty risks, etc. All this makes it necessary to study various possible instruments of project funding and their impact on the country's innovative performance.

Besides, the modern world and European trends aimed at upholding the vector of sustainable development have caused the adoption of the Decree of the President of Ukraine "On Sustainable Development Goals of Ukraine until 2030" (September 30, 2019). This regulatory document implies maintaining the priorities of sustainable innovation implementation in all areas of economic and social development on different levels in Ukraine. In this regard, the project funding approach effectively used in a state with limited resources can be a good way to finance such changes, and the impact of such funding on a country's innovation performance can be significant.

\section{LITERATURE REVIEW}

The importance of project funding as an essential element of project management can be observed in the literature and regulatory framework, as well as in the reports of leading international institutions, which reveal the conditions for such funding from foreign donors.

Over the last decades, Shenhar and Dvir (2004), Turner (2010), Seymour and Hussein (2014), Woźniak and Wawak (2020) and others have examined the project approach, but very often they do not cover the process of project funding itself as an important stage in the project process and mainly analyze project approach methods.

Among authors who paid attention to innovation process funding as a certain stage of innovation management are P. Drucker, M. Kondratiev, S. Kuznets, E. Mansfield, J. Schumpeter - the founders of innovation studies (innovatics). The national literature emphasizes that project funding is a way in which the money required for project or program implementation is provided and then granted as appropriate. Particular projects can be funded from one source or by several investors.

For a long time, the main focus in project management literature was made on management technologies and methods (H. L. Gantt, M. R. Walker, J. E. Kelley and others), but at the same time, an important matter is the raising of necessary funds for their implementation. The analysis of content of the concept "project", given in foreign sources, allows pointing out its main characteristics, components and project assessment criteria (Figure 1), which emphasizes the role of project funding in 


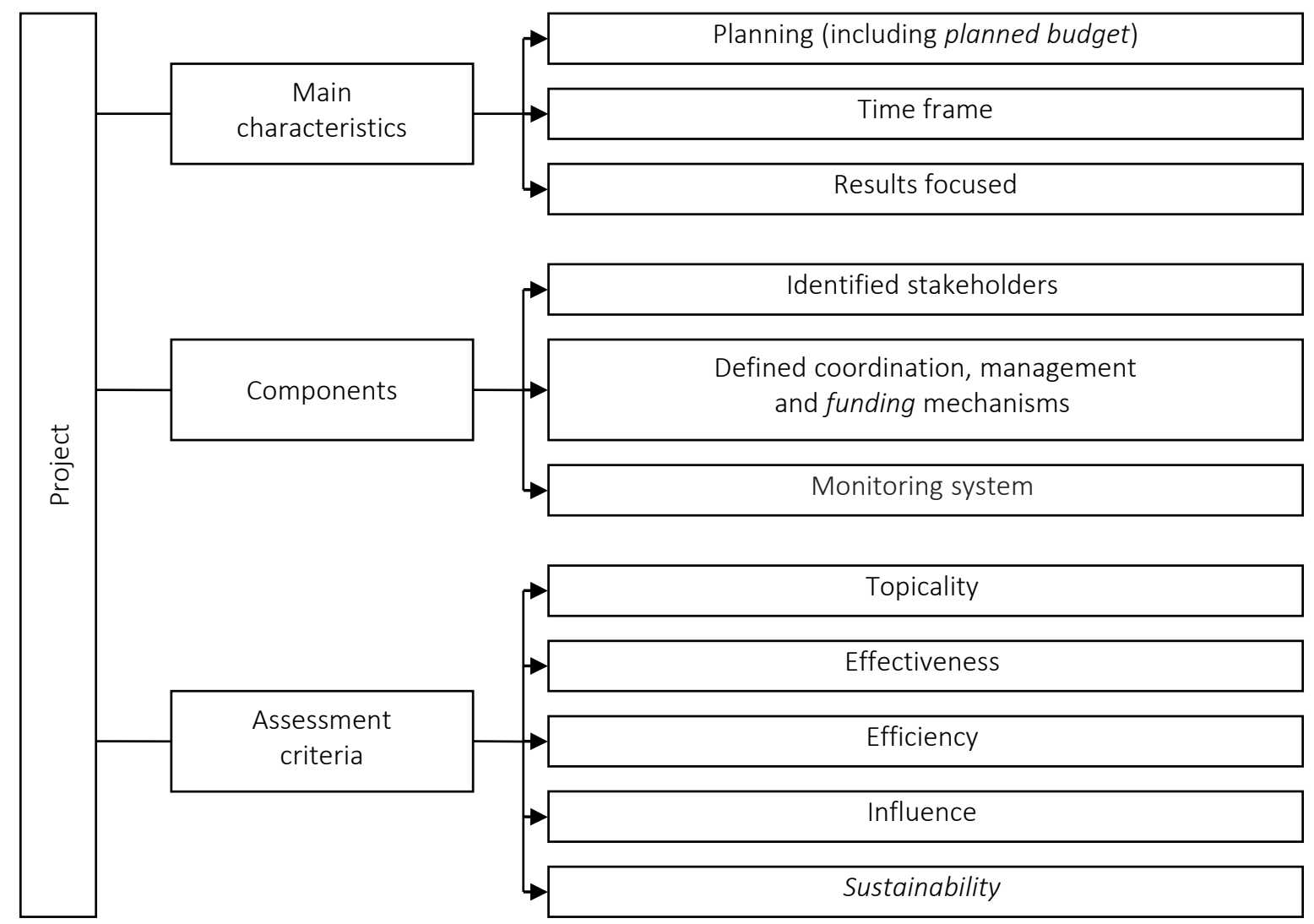

Figure 1. Comprehensive description of the project approach in the literature and regulatory framework, and the place of project funding in project management

the project management system and the factor of its sustainability in modern conditions.

For a long time, namely from the beginning of the 2000 s, in Ukraine, innovation and investment were considered in close connection in the legal framework and in scientific literature (among which the research papers of Yu. Bazhal, B. Danylyshyn, V. Osetsky, A. Peresada, Yu. Petrunia, V. Vorotin, A. Zadoia and others should be noted). At that time, the definition of an innovative project was formulated as "a set of documents with a complex of investment measures aimed at the commercialization of scientific and technical developments and new technologies in manufacturing or in social sphere" ("Regulations for the formation and use of funds of Ukrainian State Innovation Company", the main activity of which was the direct investment of innovative activity of domestic enterprises). So, the implementation of innovations is considered in close connection with investment support. Among others, in the legislation one can find a definition in which an investment project is substantiated as a set of measures (organizational, legal, managerial, analytical, financial and engineering) defined on the basis of the national system of values and tasks of innovative development of the national economy, aimed at developing certain industries, sectors of the economy, production, regions, the implementation of which is carried out by subjects of investment activity (Law of Ukraine "On Investment Activity" (1991), current version dated February 13, 2021).

In world practice, the US Project Management Institute (PMI) implemented the first regulatory standards in project management and continued their development in modern conditions. The second leading specialized project management institution is International Project Management Association (IPMA) that has 45 national associations in its structure and provides standards and guidelines for project management personnel. Nowadays, both of them provide sponsored research grants and ground the requirements to such method of research funding. 
An analysis of guidelines and reports of the European Commission about projects and programs funding demonstrates that the EU usually provides financial support in the following areas: regional and urban development, agriculture, innovation; employment and social challenges, humanitarian help, etc. Project funding is more often provided in the form of grants or contracts and, as a rule, such categories of contenders may apply for it: small and medium-sized enterprises (SMEs), non-governmental institutions and civil society organizations, youth, scientists and researchers.

According to the World Bank studies, the main trend in the development of project funding in industrial countries of Western Europe is the use of the full range of sources and methods of investment project funding, including bank loans, issue of shares, corporate loans, financial leasing, funds of industrial enterprises, etc. In some cases, state funds can also be used (sometimes in the form of government loans and subsidies, but more often in the indirect form, for example, guarantees and tax benefits). In project funding schemes, participants can be not only commercial banks, but also investment banks, investment funds and companies, pension funds and other institutional investors, leasing companies, other financial, credit and investment institutions (Lavryk \& Ponomarenko, 2017).

A special place in the literature is occupied by research papers on fundraising as a process of raising funds and other resources that an organization can not provide on its own and which are necessary for a particular project implementation or for its activity in general, that is often identified with the category "project funding" (I. Krupiak \& L. Krupiak, 2019; Holovnia, 2019; Kozak, 2018; Bhati \& Hansen, 2020 and others).

Some research relate to a definite area of project funding implementation. Thus, Carayol and Lanoe (2017), emphasizing the role of project-based approach and this way of funding in the field of innovation, research and development, focus on financial mechanisms of research project support in universities and research organizations.

Many authors pay attention to a definite form of project funding. For example, Pinto (2014) con- siders project financing from the point of view of credit funding. Franssen et al. (2018) compare institutional peculiarities of different types of innovation funding, namely, grants and prizes. Grant funding was also the subject of research papers of Harris (2019), Azoulay and Li (2020). Wahjono et al. (2015) and Fernandez-Blanco et al. (2020) examined crowdfunding as a perspective instrument in terms of limited resources. Lewandowska (2013) considered innovation project funding within the instruments such as venture capital, business angels, and leasing.

Lepori et al. (2007), while investigating public project funding, offered a methodology for measuring project funding and classified project funding in accordance with the aim of instruments into three groups: academic instruments, thematic instruments, and innovation instruments. Later Lepori et al. (2018) offered a methodology for quantitative measuring $\mathrm{R} \& \mathrm{D}$ funding.

The practice of project funding on the territory of the EU member states was analyzed by Nepelski and Piroli (2018), Zacharewicz et al. (2018). Among Ukrainian scientists, whose research was devoted to project funding, Demchuk (2010), Kostak (2015), Laktionova (2018), and Rubel (2018) should be mentioned.

Thus, the research of different authors presented in scientific literature in this field reveals certain sides of the problem, but nevertheless, a comprehensive investigation of project funding in terms of states' sustainable development remains relevant nowadays. In this context, the case study of European countries is especially important for Ukraine for project funding development, which hypothetically influences the indicators of innovation growth.

\section{METHODOLOGY}

The research methodology used in this paper included a set of empirical and theoretical and statistical methods. The first group of methods was aimed at observing the study object (project funding itself and its impact on the country's innovation growth), generalizing its proper characteristics (main features and trends in using different 
instruments of project funding in the $\mathrm{EU}$ and Ukraine), comparative analysis characterizing the field of the study (comparison of EU member states and Ukrainian experience in project funding and indicators of countries' participation in main project funding programs from 2014 to 2020). At this stage of the research process, using the methods of systematization and classification, the existing experience of the studied issue had been generalized, which allowed subsequently grouping traditional (international grant funding, domestic investment funding, project finance loans) and innovative forms of project funding (among them are business incubators, business angels, crowdfunding, venture funding, corporate venture funding, and innovative vouchers). Using the deduction method in the first dominant group of traditional instruments (international grant funding), the largest project funding programs (Horizon 2020, LIFE, COSME) were identified. On the later stage, the influence of participation in each program on the innovation infrastructure development and innovation performance of a country was determined.

The second group of statistical methods were used to investigate the dynamics of project funding under the Horizon 2020 program, which was considered in terms of the following groups of indicators reflecting specific areas of funding: advanced science, industrial leadership, and social challenges.

The analysis of quantitative characteristics of project funding in the EU countries under the Horizon - 2020 program was carried out on the basis of the following indicators: participation - number of organizations involved in the Horizon - 2020 program; share of participants from the country to the EU total participants, \%; net EU contribution - amount of funds received by the project's participants from EU institutions, billion euro; share of funding received by the country in the EU total, \%; SME participation - number of SMEs involved in Horizon - 2020 projects; share of SMEs in a country total, \%; participation rank - ranking position based on the participation in Horizon - 2020.

The investigation of the innovation climate of the EU member states participated in the Horizon 2020 program was carried out using the criteria mentioned in Table 2. To point out the EU countries - leaders in project funding program participation, the method of ranking was used. EU member states were ranked by the place occupied in the ranking of participation in the Horizon - 2020 program, and the innovation climate of top 10 countries was examined.

Using generalization and abstraction at the concluded stages of the study, the correlation between the above innovation climate criteria, which form the countries' innovation portfolio, and key indicators of countries' participation in leading project funding programs was determined. The relationship between the project life cycle and innovative forms of funding was also established.

\section{RESEARCH RESULTS}

The analysis of traditional forms of project funding of sustainable innovations in the world allows pointing out some consolidated categories (Figure 2): international grant funding, domestic investment funding, and project finance loans.

\subsection{International grant funding}

Projects applying for international grant funding are developed in accordance with the requirements of international institutions and their goals. Furthermore, a majority of projects for grant funding are smaller and attract less money compared to the funds that can be invested by large private investors. In addition, among the main problems of raising international technical assistance to the particular projects are: the discrepancy between international institutions' program objectives and the needs of the regions where the participants in the declared projects are based; insufficient development and non-compliance of regional infrastructure with the requirements of international grant funding programs; limited amount of funds and time limit for its using; the process of project selection usually takes a long time; the receipt of grant funds is taking place gradually and relatively slowly; the grant funds often do not cover the operating and overhead costs of the project; etc. The goals of a project had to solve a problem that international organizations offer to deal with, but very often they do not correspond to the transformation processes in Ukraine. A necessary prerequisite is also a willingness to continue the project implementation after the financial assistance ter- 


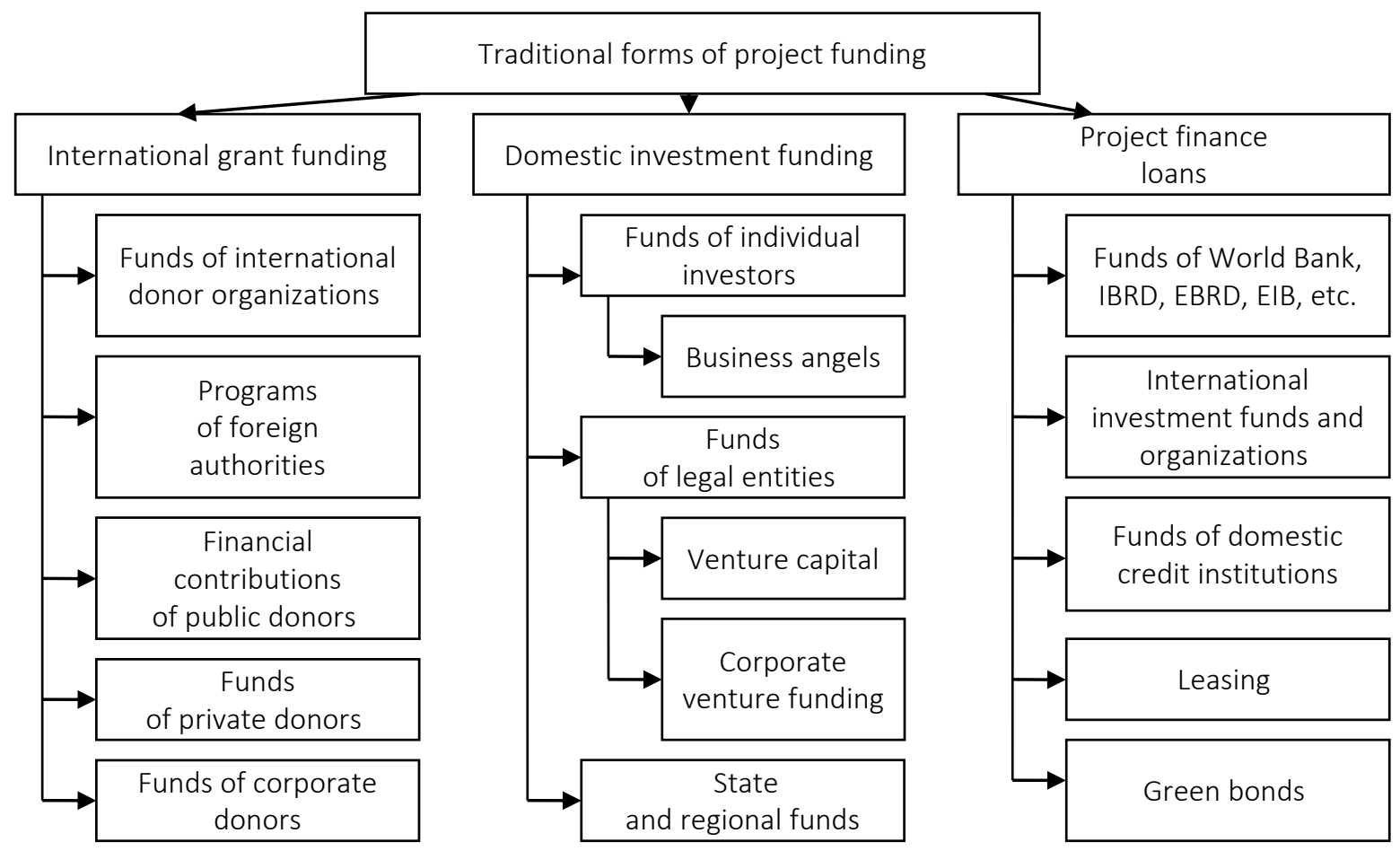

Figure 2. Traditional forms of project funding

mination. On average, international donors provide loans in the amount of 50 to 400 thousand euro (with a repayment period of 4 to 8 years), whereas Ukrainian lending programs for small and medium-sized enterprises allocate funds in the amount of 25 to 500 thousand dollars.

International grant funding can be provided:

- from the funds of international donor organizations (intergovernmental institutions, in particular, the United Nations (for example, United Nations Development Program (UNDP), UNICEF, World Bank, CommunityBased Adaptation (CBA)) and the European Union (European Commission, Council of Europe, OSCE));

- through the programs of foreign authorities (USAID, Canadian International Development Agency (CIDA), Swedish International Development Cooperation Agency (SIDA), etc.) or foreign embassies in Ukraine (Germany, Norway and other countries);

- from financial revenues of public donors (for example, PHARE - Democracy Program, International Visegrad Fund);
- from private donor funds (it varies from large international funds among which are "Vidrodzhennia" Foundation sponsored by G. Soros, the Rockefeller Foundation to small family funds);

- corporate donors (through corporate social responsibility programs implemented by large companies, such as Monsanto, Shell, etc.).

The largest European project funding program, including financing for sustainable innovations, is Horizon 2020, a research and innovation program that provides additional funding for innovation projects (Figure 3).

The Program includes: Framework Program for Research and Technological Development; Competitiveness and Innovation Framework Program (CIP); European Institute of Innovation and Technologies (EIT). Since 2021, the program has been transformed into Horizon Europe, the EU's research and innovation program, which will last until 2027, with a budget of 95.5 billion euro, aimed at solving of the climate change problem, promoting the sustainable development goals and increasing the EU's competitiveness and growth. 


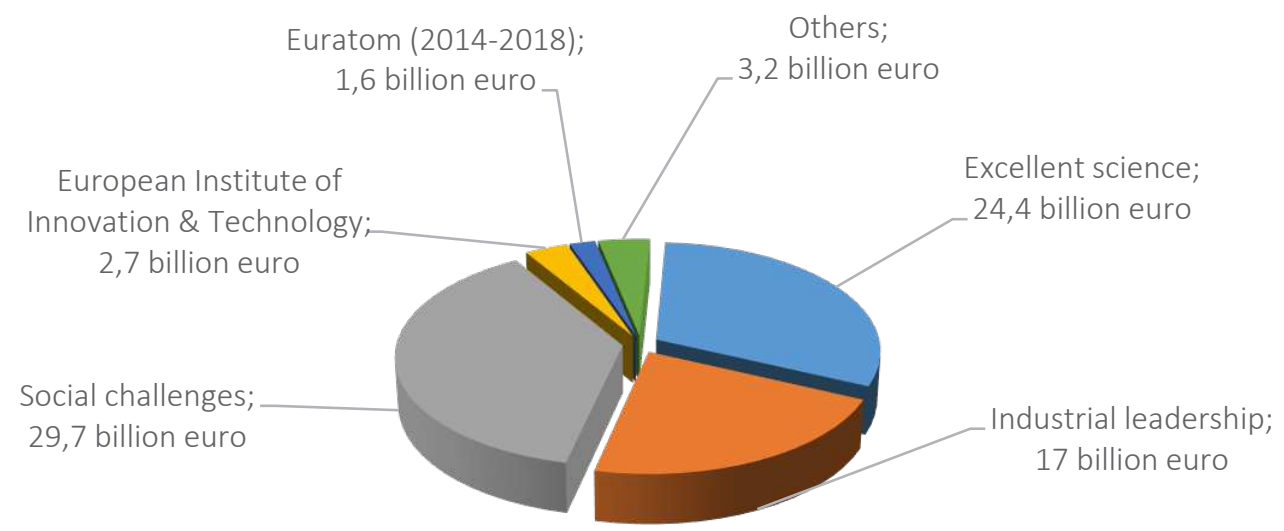

- Industrial leadership

European Institute of Innovation \& Technology

- Others

Figure 3. Horizon 2020 project funding program budget

Small and medium-sized enterprises have considerable innovation potential and sufficient dynamism to implement technological developments and bring innovative services to the market. The program for SMEs within the Program implies funding of the following project categories:

- leadership in providing and creating industrial technologies (information and communi- cation technologies, nano- and biotechnology, manufacturing, etc.);

- access to risk funding (use of private funds and venture capital);

- innovation in small and medium-sized enterprises (SMEs) (Figure 4).

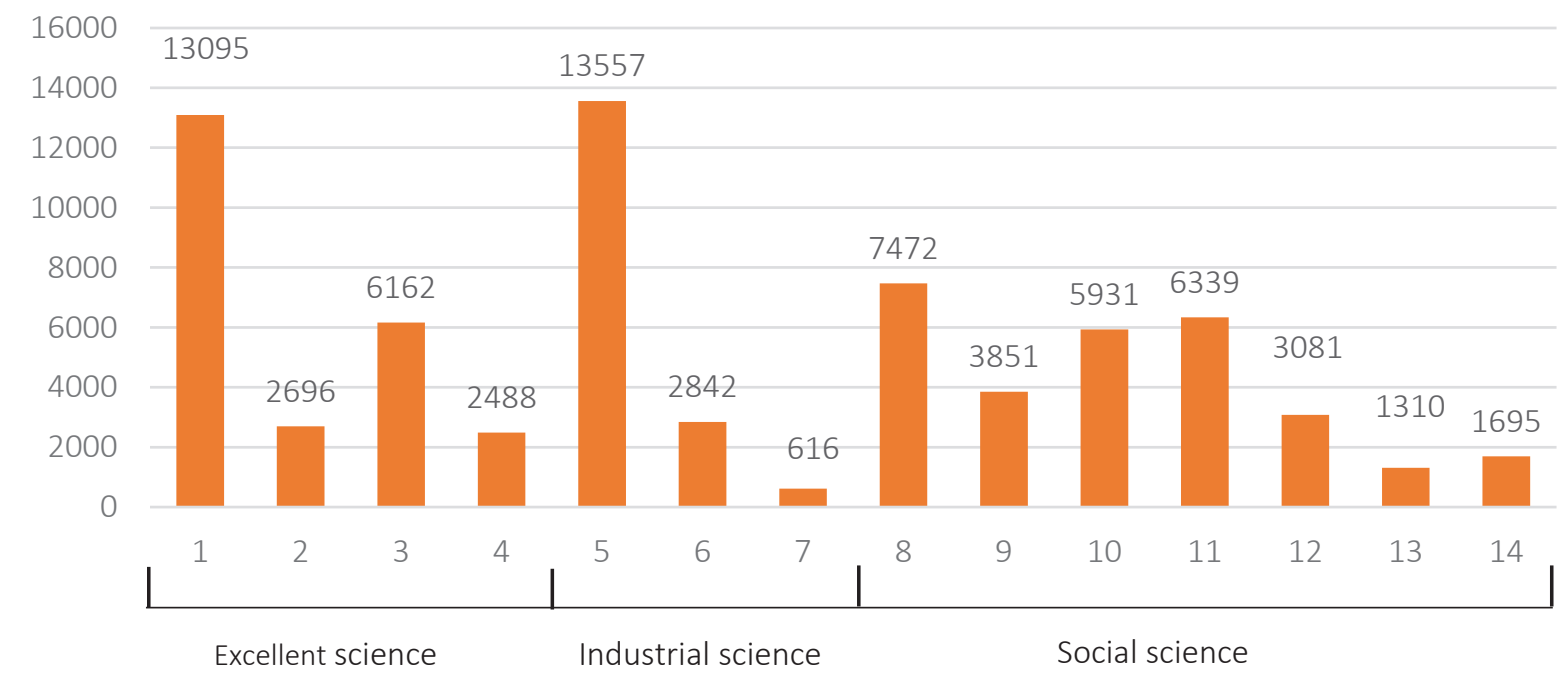

Note: 1 - European Research Council (ERC) - advanced research of the best particular groups. 2 - technologies of the nearest and distant future - joint research aimed at discovering new innovative industries. 3 - activities within the program of Marie Sklodowska-Curie Foundation (MSCA) - human resource development in the industry. 4 - research infrastructure. 5 - leadership in providing and creating innovations in the industrial sectors (LEIT) - information and communication technologies, nano- and biotechnologies, manufacturing, etc. 6 - access to risk funding - use of private funds and venture capital. 7 - innovation in small and medium business - support for all forms of innovations provided by small and medium-sized enterprises (SMEs). 8 - health, welfare of the nation, demography. 9 - indicators related to sustainable development of natural resources. 10 - energy efficiency and energy saving. 11 - sustainable transport systems development. 12 - climate and environmental protection. 13 - sustainable and effective communities. 14 - secure communities.

Figure 4. Funding for projects under the Horizon 2020 program, 2014-2020 (million euro) 
The analysis of quantitative indicators of project funding of the participants from the EU countries under the Horizon - 2020 program (Table 1) allowed identifying a number of tendencies:

- a major part of program's participants are the residents of countries such as Germany, Spain, France, Italy and the Netherlands (from 15.8 thousand to 19.3 thousand participants), representing $54.2 \%$ of the total number of program's participants from EU member states;

- consequently, the above-mentioned top 5 countries participating in the program have the largest amount of raised funds on project implementation (Germany - 9.44 billion euro, Spain - 5.88 billion euro, France - 10.99 billion euro, Italy - 5.26 billion euro, and the Netherlands -4.88 billion euro);

- the average share of small and medium-sized enterprises in the countries participating in the program stands at $21.2 \%$ (the highest rate is registered in Cyprus - $40.6 \%$, the lowest one is in Croatia $-13.7 \%$ and Romania $-13.8 \%$ ).

The EU member states are then ranked according to the place occupied in the ranking of participation in the Horizon 2020 program, and their innovative climate is investigated (Table 2).

Table 1. Quantitative indicators of project funding in EU countries under the Horizon - 2020 program

\begin{tabular}{|c|c|c|c|c|c|c|c|}
\hline Country & $\begin{array}{l}\text { Participation, } \\
\text { number of } \\
\text { organizations } \\
\text { involved in } \\
\text { the program }\end{array}$ & $\begin{array}{l}\text { Share of } \\
\text { participants } \\
\text { from the } \\
\text { country to } \\
\text { the EU total, } \\
\%\end{array}$ & $\begin{array}{c}\text { Net EU } \\
\text { contribution, } \\
\text { funds } \\
\text { received by } \\
\text { the project's } \\
\text { participants } \\
\text { from EU } \\
\text { institutions, } \\
\text { billion euro }\end{array}$ & $\begin{array}{l}\text { Share of } \\
\text { funding } \\
\text { received by } \\
\text { the country } \\
\text { in the EU } \\
\text { total, \% }\end{array}$ & $\begin{array}{c}\text { SME } \\
\text { participation, } \\
\text { number } \\
\text { of SMEs } \\
\text { involved in } \\
\text { the program }\end{array}$ & $\begin{array}{c}\text { Share of } \\
\text { SMEs in the } \\
\text { country total, } \\
\%\end{array}$ & $\begin{array}{c}\text { Ranking } \\
\text { position } \\
\text { based on the } \\
\text { participation } \\
\text { in the } \\
\text { program }\end{array}$ \\
\hline Austria & 4666 & 3,22 & 1,8 & 3,14 & 1045 & 22,4 & 9 \\
\hline Belgium & 7693 & 3,32 & 3,13 & 5,47 & 1662 & 21,6 & 7 \\
\hline Bulgaria & 886 & 0,61 & 0,14 & 0,25 & 196 & 22,12 & 23 \\
\hline $\begin{array}{l}\text { United } \\
\text { Kingdom* }\end{array}$ & 16611 & 11,35 & 7,53 & 13,03 & 2872 & 17,29 & 3 \\
\hline Greece & 5012 & 3,46 & 1,55 & 2,71 & 1184 & 23,62 & 11 \\
\hline Denmark & 3671 & 2,54 & 1,64 & 2,86 & 767 & 20,89 & 10 \\
\hline Estonia & 817 & 0,56 & 0,24 & 0,42 & 223 & 27,29 & 21 \\
\hline Ireland & 2732 & 1,89 & 1,11 & 1,93 & 695 & 25,44 & 13 \\
\hline Spain & 17335 & 11,98 & 5,88 & 10,27 & 4192 & 24,18 & 4 \\
\hline Italy & 15772 & 10,9 & 5,26 & 9,19 & 3554 & 22,53 & 5 \\
\hline Cyprus & 894 & 0,62 & 0,3 & 0,51 & 363 & 40,6 & 19 \\
\hline Latvia & 500 & 0,35 & 0,1 & 0,18 & 74 & 14,8 & 26 \\
\hline Lithuania & 575 & 0,4 & 0,89 & 0,16 & 119 & 20,7 & 27 \\
\hline Luxembourg & 602 & 0,42 & 0,19 & 0,33 & 144 & 23,92 & 22 \\
\hline Malta & 224 & 0,15 & 0,33 & 0,06 & 39 & 17,41 & 28 \\
\hline Netherlands & 10129 & 7 & 4,88 & 8,51 & 2222 & 21,94 & 6 \\
\hline Germany & 19293 & 13,33 & 9,44 & 16,48 & 3534 & 18,32 & 1 \\
\hline Poland & 2651 & 1,83 & 0,71 & 1,23 & 489 & 18,45 & 15 \\
\hline Portugal & 3589 & 2,48 & 1,06 & 1,85 & 797 & 22,21 & 14 \\
\hline Romania & 1481 & 1,02 & 0,27 & 0,48 & 204 & 13,77 & 20 \\
\hline Slovakia & 648 & 0,45 & 0,13 & 0,23 & 151 & 23,3 & 24 \\
\hline Slovenia & 1348 & 0,93 & 0,35 & 0,61 & 316 & 23,44 & 18 \\
\hline Hungary & 1424 & 0,98 & 0,35 & 0,61 & 396 & 27,81 & 17 \\
\hline Finland & 3230 & 2,23 & 1,44 & 2,51 & 596 & 18,45 & 12 \\
\hline France & 15909 & 10,99 & 6,97 & 12,17 & 2767 & 17,39 & 3 \\
\hline Croatia & 728 & 0,5 & 0,12 & 0,21 & 100 & 13,74 & 25 \\
\hline Sweden & 4809 & 3,32 & 2,15 & 3,75 & 804 & 16,72 & 8 \\
\hline
\end{tabular}

Note: ${ }^{*}$ at the time of EU membership. 
Table 2. Innovation climate indicators of the EU countries based on the rating of participation in the Horizon - 2020 program

\begin{tabular}{|c|c|c|c|c|c|c|c|c|c|}
\hline \multirow{2}{*}{ Country } & \multirow{2}{*}{ Rank } & \multicolumn{8}{|c|}{ Criteria } \\
\hline & & 1 & 2 & 3 & 4 & 5 & 6 & 7 & 8 \\
\hline Germany & 1 & 3 & 4 & 13,72 & 24 & 5 & 5,8 & 11,4 & Strong innovator \\
\hline United Kingdom * & 2 & 1,7 & 11 & 9,17 & 9 & 10 & 2,9 & 15,3 & Strong innovator \\
\hline France & 3 & 2,3 & 7 & 8,85 & 32 & 12 & 3,5 & 11 & Strong innovator \\
\hline Italy & 4 & 1,2 & 17 & 11,21 & 30 & 20 & 1,3 & 9,2 & Moderate innovator \\
\hline Spain & 5 & 1,4 & 12 & 9,42 & 51 & 22 & 2,1 & 10,4 & Moderate innovator \\
\hline Netherlands & 6 & 2 & 8 & 5,25 & 36 & 6 & 4,9 & 14,6 & Strong innovator \\
\hline Belgium & 7 & 2,6 & 6 & 3,43 & 45 & 7 & 3,4 & 12,4 & Strong innovator \\
\hline Sweden & 8 & 3,3 & 1 & 2,47 & 12 & 2 & 6,3 & 11,9 & Innovation leader \\
\hline Austria & 9 & 3,2 & 2 & 2,08 & 26 & 4 & 4,7 & 10,8 & Strong innovator \\
\hline Denmark & 10 & 3,1 & 3 & 1,74 & 3 & 1 & 4,8 & 13 & Strong innovator \\
\hline Greece & 11 & 1,1 & 18 & 2,63 & 72 & 16 & 0,8 & 8,6 & Moderate innovator \\
\hline Finland & 12 & 2,8 & 5 & 1,82 & 17 & 3 & 5,4 & 10,5 & Innovation leader \\
\hline Ireland & 13 & 1,1 & 19 & 1,29 & 23 & 13 & 1,8 & 12 & Strong innovator \\
\hline Portugal & 14 & 1,3 & 14 & 3,46 & 34 & 11 & 1,2 & 8,9 & Moderate innovator \\
\hline Poland & 15 & 1 & 20 & 9,04 & 33 & 18 & 0,8 & 4,9 & Moderate innovator \\
\hline Hungary & 17 & 1,4 & 12 & 2,57 & 53 & 19 & 2 & 6,3 & Moderate innovator \\
\hline Slovenia & 18 & 1,9 & 9 & 0,85 & 40 & 9 & 2,6 & 8,4 & Moderate innovator \\
\hline Cyprus & 19 & 0,6 & 25 & 0,36 & 57 & 27 & 0,6 & 8,4 & Moderate innovator \\
\hline Romania & 20 & 0,5 & 28 & 1,26 & 52 & 28 & 0,4 & 4,6 & Modest innovator \\
\hline Estonia & 21 & 1,3 & 15 & 0,89 & 16 & 15 & 1,8 & 7,6 & Moderate innovator \\
\hline Luxembourg & 22 & 1,3 & 16 & 0,19 & 66 & 8 & 2,4 & 13,1 & Strong innovator \\
\hline Bulgaria & 23 & 0,8 & 24 & 0,68 & 59 & 23 & 0,9 & 3,6 & Modest innovator \\
\hline Slovakia & 24 & 0,9 & 21 & 1,83 & 42 & 21 & 1,1 & 5,7 & Moderate innovator \\
\hline Croatia & 25 & 0,9 & 23 & 0,81 & 58 & 24 & 0,8 & 4,2 & Modest innovator \\
\hline Latvia & 26 & 0,5 & 27 & 0,59 & 19 & 26 & 0,6 & 5,9 & Moderate innovator \\
\hline Lithuania & 27 & 0,9 & 21 & 0,79 & 14 & 17 & 0,7 & 4 & Moderate innovator \\
\hline Malta & 28 & 0,6 & 26 & 0,92 & 84 & 25 & 1,8 & 10,5 & Moderate innovator \\
\hline
\end{tabular}

Note: * at the time of EU membership. Criteria: $1-$ R\&I intensity - total intramural R\&D expenditure as a GDP percentage (EU average 2,1\%). $2-R \&$ Intensity ranking - ranking position based on the total intramural R\&D expenditure as a percentage of GDP (among 28 EU countries). 3 - EU contribution to R\&I - Horizon - 2020 contribution to R\&I in EUR and contribution from European Structural and Investment funds, billion euro. 4-ease of Doing Business rank - World Bank Index ranking the country on the ease of doing business (among 190 countries). 5 - place of a country in the EU country ranking, based on the number of researchers per million population. 6 - patent applications rate - patent applications per billion GDP in current Purchasing Power Standards (PPS in euro) (EU average 3,3). 7 - top cited publications rate - percentage of scientific publications within the $10 \%$ most cited scientific publications worldwide (EU average 11,1\%). 8 - general innovation performance of a country according to the European Innovation Scoreboard 2019.

Analyzing the impact of the ranking position based on the participation in project funding programs of enterprises of a particular country, the link with the patent rate per billion of GDP (for example, this figure is significantly higher than the average in the top ten countries: Germany - 5.8, the Netherlands - 4.9, Sweden - 6.3, Denmark - 4.8, and Austria - 4.7) can be traced. Also, the top 10 countries of the rank are represented mostly by those of them which belong to the group of "Strong innovators", one country is the "Innovation leader" (Sweden), and only two of them are "Moderate innovators" (Spain and Italy).

Ukraine's participation in the Horizon - 2020 program can be shown in Table 3. Nowadays, there are about 350 thousand enterprises in Ukraine, but no more than 5 thousand have ever participated in grant programs (particularly, about 300 in the Horizon - 2020 program).

The second largest program regarding the scope of sustainable innovation project funding, according to this study, is the LIFE program - the EU financial instrument, a program of environmental and climate change prevention research that provides grants and additional funding tools for innovative projects. Since 1992, the LIFE program has co-financed more than 4,500 projects. Between 2014 and 2020, about 3.4 billion euro was raised through the LIFE program for sustainable project implementation. 
Table 3. Quantitative indicators of project funding in Ukraine under the Horizon - 2020 program

\begin{tabular}{l|c}
\hline \multicolumn{1}{c}{ Characteristic } & Indicator value \\
\hline Number of organizations involved in the program & 305 \\
Share of participants from the country to the associated EU members total, $\%$ & 2,42 \\
Funding received by the project's participants, billion euro & 0,44 \\
Share of funding received by the country to the associated EU members total, \% & 0,78 \\
\hline Ranking position among associated EU members based on the participation in the program & 7 \\
\hline
\end{tabular}

Also of note is the COSME program, which is one of the EU's large-scale programs with a budget of 2.3 billion euro, aimed at creating favorable conditions for the competitive development of small and medium-sized enterprises that could be defined as a promising sector for innovation creation and implementation. Ukraine's adherence to the European COSME program provided access for domestic companies to the program budget of about 900 million euro.

During the period from 2014 to 2020 , financial resources were raised in the form of grants to fund the projects of small and medium-sized enterprises that had been provided innovation activity. A very important advantage of this program is the support of cluster cooperation, which could be considered a powerful subject in generating innovations. The data shown in Figure 5 can serve an illustrative example of this.

There are approximately 50 cluster initiatives and clusters in Ukraine, and 22 of them are presented on the European Cluster Collaboration Platform
(ECCP). In general, it can be counted about 30 cluster organizations officially registered in the state and engaged in the following types of economic activities (Figure 6).

A major part of clusters registered and operating in Ukraine are engaged in IT innovation (for example, there is a powerful IT cluster in Lviv, uniting 65 companies; Kharkiv IT cluster develops the city's IT ecosystem and innovation environment for technology business) and in sustainable agricultural production. For instance, the cluster project for manufactures of ecological products is functioning in Poltava region; the UkrainianRomanian "First Agrarian Cluster" was created in Chernivtsi region and unites fruit and berry manufactures; a regional agro-industrial "Agroinnovation" cluster was created in Rivne and focused on developing and implementing innovations in the agro-industry of the region; a food processing cluster has been established in Vinnytsia region in the framework of the EU Project for Support of Sustainable Regional Development (SSRD).

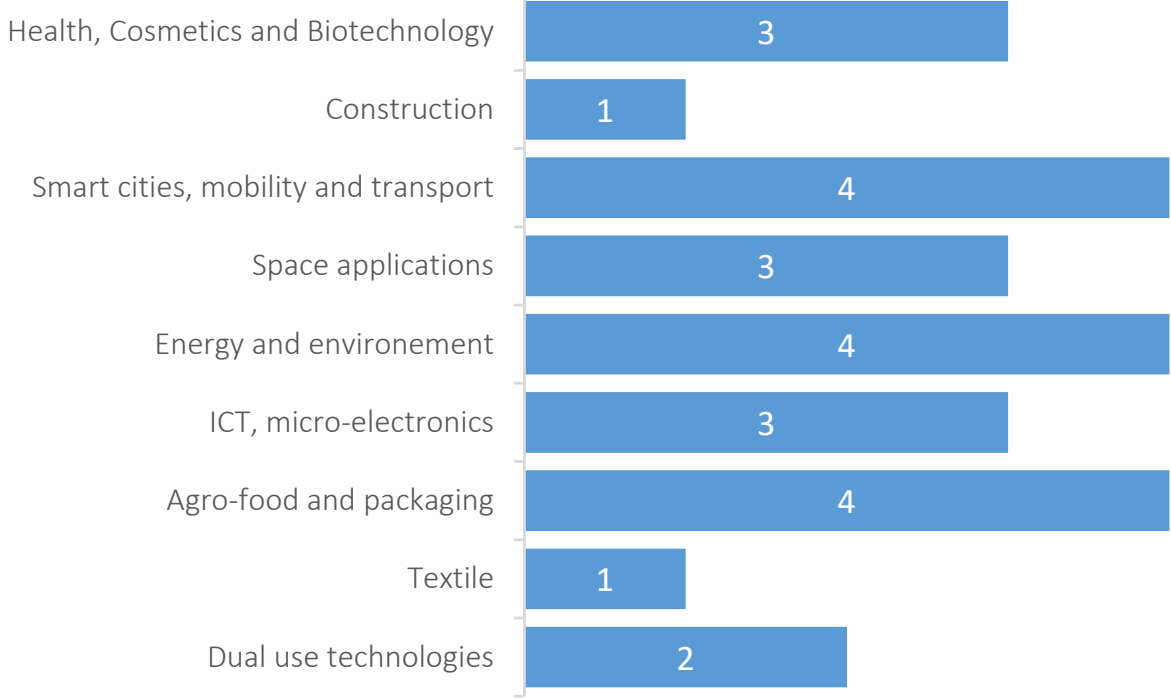

Figure 5. Strategic innovation clusters based on the cooperation within the partnership under the COSME program in 2018-2019 


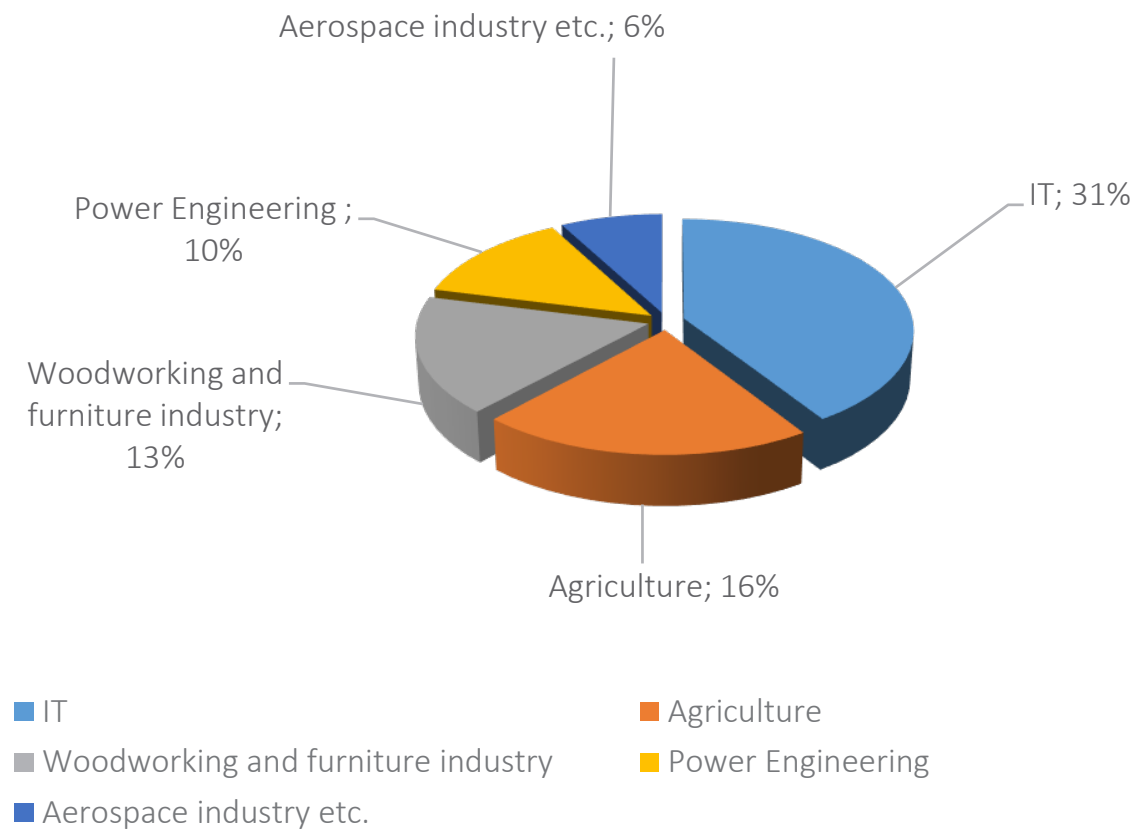

Figure 6. Distribution of clusters in Ukraine by type of economic activity

Until 2020, the vector of cluster development was poorly supported by the state. In particular, there were no responsible bodies in the central government, relevant national policies or programs. However, these processes have recently intensified in Ukraine, especially at the regional level. European cluster practice is controversial, but appropriate policies have already been implemented at the national level in Austria, the Czech Republic, Denmark, Estonia, France, Germany, Poland and others. Public and regional authorities and institutions, as well as private companies and non-governmental organizations (venture investors, state research institutions, regional authorities, etc.), can initiate and coordinate the creation of clusters. In general, it can be noted that enterprises belonging to clusters are more successful in the development and implementation of sustainable innovations.

\subsection{Domestic investment funding}

Domestic investment funding means financing of the projects of individuals, legal entities, united territorial communities and so on by domestic investors, often represented by large enterprises or state funds. This approach implies greater specificity and compliance with the project's regional needs, as well as with the investor's requirements that is often achieved by joint collaboration and partnership between project participants, for example, between a large enterprise and a united territorial community. Moreover, this approach involves financing of their own environmental projects by the particular companies.

Examples of successfully implemented projects of this type in Ukraine are the following: building of a biogas plant on the dairy farm of Ukrainian Milk Company (Kyiv region), which produces electricity from biogas; building of a biogas plant by Avangard agroholding (KamianetsPodilskii, Kherson region); building of wind farms by Donbass Fuel and Energy Company (in Zaporizhzhia and Donetsk regions); building of a small hydroelectric power plant by Novosvit Company (Vinnytsia region); building of a modern metallurgical plant by the Interpipe group (Dnipro City); building of a pellet plant PelletEnergy (Zhytomyr region); Euro Cape Ukraine project on building, exploitation and maintenance of wind power plants (Zaporizhzhia region) (30\% of construction is invested from the company's own resources, other $70 \%$ are raised funds).

Funding for regional projects in Ukraine is becoming more widespread through funding from state funds, for example, the State Fund for Regional Development (Figure 7). This Fund is one of the important instruments of the state, which em- 


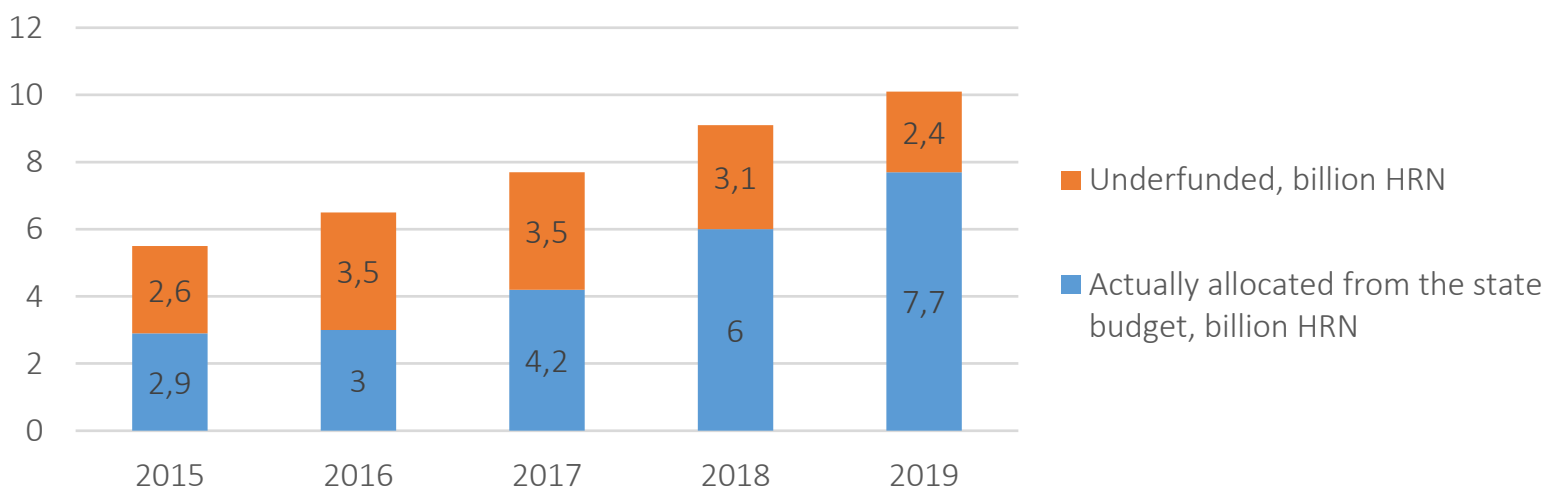

Figure 7. Funding of regional development projects by the State Fund for Regional Development

bodies the vector of balanced and sustainable economic and social development of regions.

Government budget for 2021 provides 4.5 billion hryvnias to the State Fund for Regional Development. At the same time, the regions have already received proposals for funding from the State Fund for Rural Development of 294 projects totaling 4.2 billion $\mathrm{UAH}$, and 148 of them are the projects beginning in the previous years.

As for domestic investment funding projects, the special attention is attracted by the latest innovative forms of project funding (Figure 8):

- a business incubator is one of the organizational forms of innovation, which has the form of a registered entity (as separate organization, in higher educational institution, at industrial enterprises, etc.), whose activity is aimed at providing support (financial, consulting, managerial, administrative, etc.) to projects or enterprises at the initial stages of their life cycle (commonly, start-ups). According to statistics, there are more than 4,000 business incubators in the world, including about 800 in Western Europe, and a little more than 20 in Ukraine (however, in fact, on average only 10 of them are well-functioning);

- business angels are large private informal investors providing financial support, information, advisory or managerial assistance, investing in earlier risky stages of projects, often existing in the form of funds, networks, groups (for example, European Business Angels Network (EBAN)). In Ukraine, the electronic network UAngel has been launched since 2012, where the following groups of domestic investors can choose projects that are attractive for investment;

- corporate venture funding is used by large enterprises to invest in innovative start-ups in order to improve corporate competitiveness or for other strategic or financial purposes. Venture capital is a financial instrument used in the later, but less dangerous and risky stages of growth. About 15\% of such kind of investments is concentrated in Western Europe (for example, Scottish Mutual Fund in the United Kingdom);

- crowdfunding is the way of raising public or private funds to finance projects. The financial model includes equity crowdfunding (equitybased crowdfunding) and credit crowdfunding (crowdlanding). Equity-based crowdfunding involves obtaining by a sponsor of the share in the company's business at the early stage of its development. This type of crowdfunding gives an opportunity to sponsors to invest small amounts of money in non-public companies;

- innovation vouchers are a tool to support small and medium-sized enterprises in purchasing services $(R \& D$, intellectual property rights, innovation management, etc.). This practice is common for Cyprus, Germany, Belgium, Austria, Greece, Spain, Hungary, and Slovenia. Vouchers are issued by regional or national agencies with an obligation to make a payment to a service provider, they are 


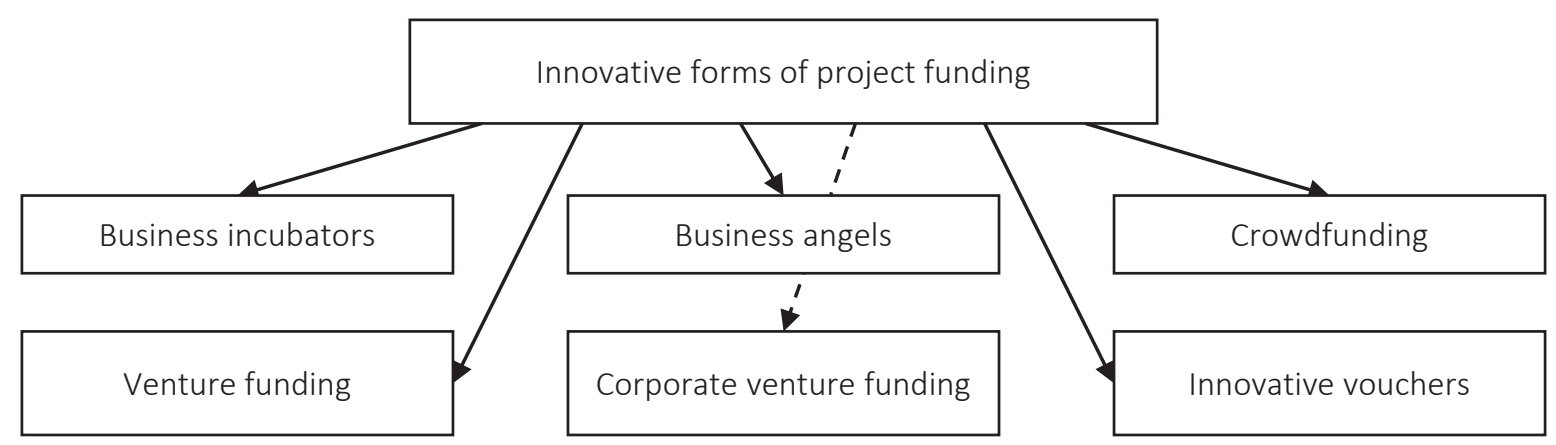

Figure 8. Innovative forms of project funding

limited by the amount of provided funds (average maximum 20 thousand euro).

Analysis of the correlation between the project's life cycle and innovative forms of funding shows that funds are more frequently invested in startups and projects at the early stages of their implementation, consequently, funding tools in this phase are more diversified (business incubators, business angels, corporate venture funding, crowdfunding, etc.). At the later stage of project implementation, innovation vouchers and venture capital are more commonly used (Figure 9).

\subsection{Project finance loans}

This type of financing is allocated from borrowed funds on the principles of repayment and payment and is provided at a certain interest rate on the definite term, however, which may be lower than a regular commercial loan. The largest international creditors in financing environmental projects, eco-innovations, energy efficiency and other issues related to sustainable development are the World Bank, the International Bank for Reconstruction and Development, the European Bank for Reconstruction and Development, European Investment Bank, Organization for

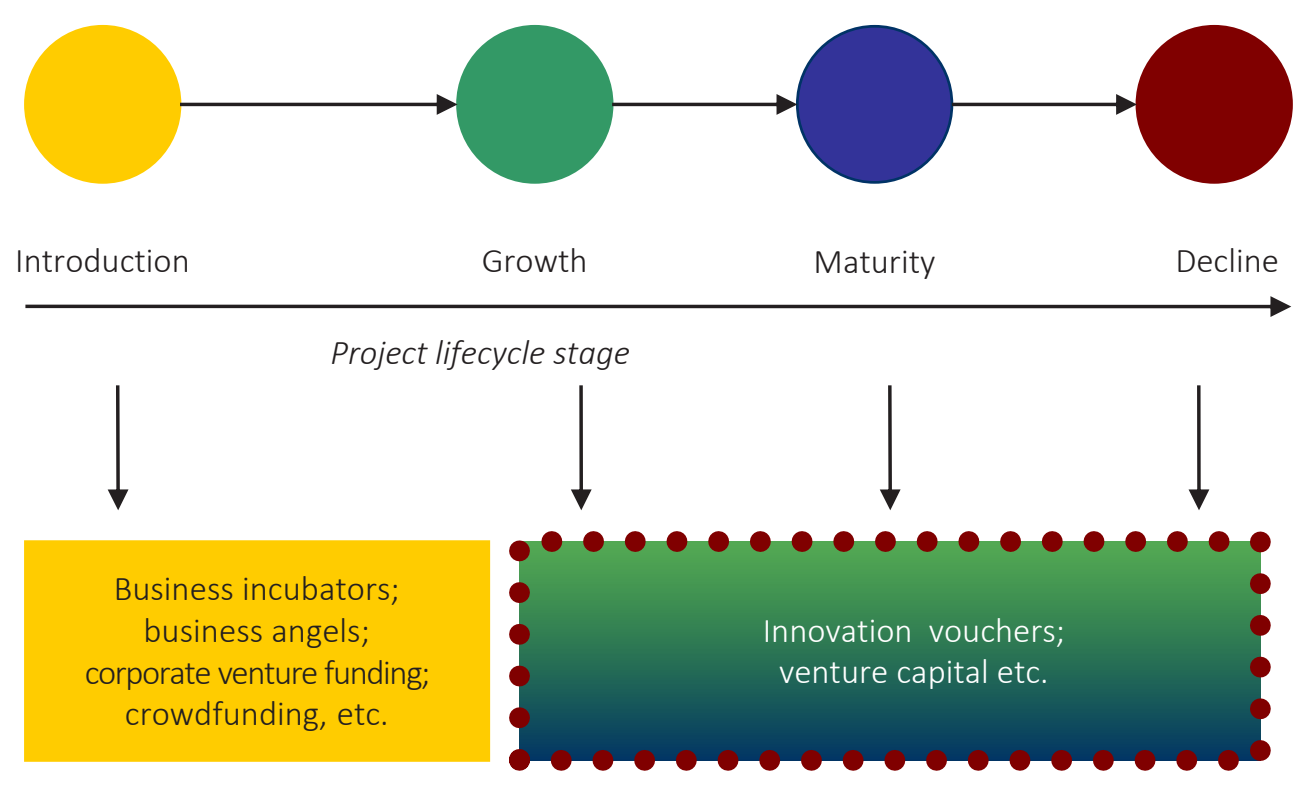

Innovative form of funding

Figure 9. Correlation between the stage of the project life cycle and innovative forms of funding 
Economic Cooperation and Development, international investment funds and organizations.

Commercial bank loans on ecological innovations are also becoming more widespread (for example, Ukrgasbank became the first commercial bank that actively supports environmental programs and projects). However, not all projects can receive credit funding and should be clearly justified for the institutions that allocate these funds. Moreover, a common practice for Ukrainian enterprises are the use of lease contracts (financial instrument for the rent of fixed assets by enterprises or individuals with the option of its further purchase). Among innovative instruments for Ukraine in this context of research, "green bonds" can be named (loan financial instruments, which are used only for green projects funding), but they are only planned to be used by government.
Compared to the European experience, this practice in Ukraine is an empty niche. But in EU countries, as well as in Ukraine, the sphere of "green investment" can be increasingly attractive for commercial banking institutions, especially funding renewable energy, energy saving in households, etc., since it also meets the interests of the commercial sector and can be the way of co-funding of this sphere on the principles of partnership attracting banking institutions. In this context, state measures to stimulate such funding (in particular, low loan rates for green projects, etc.) may be important. In general, a bank loan is used as one of the most common tools for access to finance. But the possibility of providing green loans depends on the capacity of a banking institution, as well as market conditions and the regulatory environment.

\section{CONCLUSION}

This study was aimed at revealing the relationship between different project funding instruments and innovation performance of the state or its separate elements. As a result, based on the systematization of practical experience of the EU member states and Ukraine, the forms of sustainable innovation project funding were grouped (traditional, including international grant funding, domestic investment funding, project finance loans, and relatively innovative, especially for Ukraine, in particular, business incubators, innovation vouchers, crowdfunding, etc.).

The analysis of state participation in these processes allowed identifying that only a small part of projects (as a rule, projects of regional or state importance, projects of united territorial communities, etc.) are directly funded by the state or its respective institutions and bodies. The experience of European countries with high rates of innovative development, which occupy leading positions in the ranking of their enterprises in key international grant programs, shows that they use those tools that mainly indirectly affect the development of this area (in particular, creation of appropriate innovation infrastructure - innovation clusters, business incubators etc., improving the conditions of doing business in the country and so on). This generally affects the development and innovative potential of small and medium-sized business in the country, which is the main "conductor" in the field of implementing innovations, including sustainable innovations.

The study showed that not all project funding instruments are widely used (for example, innovation vouchers and green bonds have not yet become widespread in the innovation sphere). In general, it has been concluded that the state's efforts should be focused on two priority vectors of development in this area: the first one is to strengthen project activities in the country and ensure the attractiveness of innovative projects for domestic investors in order to attract funds from internal sources; the second is to support domestic small and medium-sized enterprises in attracting money from international funds (in particular, funds of leading European institutions), especially under limited domestic sources. As a result, this will ensure the innovative growth of the state within the sustainable development vector. 


\section{AUTHOR CONTRIBUTIONS}

Conceptualization: Viktor Oharenko, Anzhela Merzlyak, Viktoriia Tomareva-Patlakhova.

Data curation: Iuliia Vikhort, Dariia Skriabina.

Investigation: Viktor Oharenko, Anzhela Merzlyak, Viktoriia Tomareva-Patlakhova, Iuliia Vikhort,

Daria Skriabina.

Formal analysis: Viktoriia Tomareva-Patlakhova, Daria Skriabina.

Methodology: Viktor Oharenko, Anzhela Merzlyak, Viktoriia Tomareva-Patlakhova.

Project Administration: Viktoriia Tomareva-Patlakhova.

Resources: Iuliia Vikhort, Daria Skriabina.

Supervision: Viktor Oharenko, Anzhela Merzlyak.

Validation: Iuliia Vikhort.

Visualization: Iuliia Vikhort, Daria Skriabina.

Writing - original draft: Viktor Oharenko, Anzhela Merzlyak, Viktoriia Tomareva-Patlakhova, Iuliia Vikhort, Daria Skriabina.

Writing - rewiew and editing: Viktor Oharenko, Anzhela Merzlyak.

\section{REFERENCES}

1. Azoulay, P., \& Li D. (2020). Scientific Grant Funding. NBER Working Papers. National Bureau of Economic Research, Inc. Retrieved from https://www.nber. org/system/files/working_papers/ w26889/w26889.pdf

2. Bhati, A., \& Hansen, R. K. (2020). A literature review of experimental studies in fundraising. Journal of Behavioral Public Administration, 3(1), 1-19. https://doi. org/10.30636/jbpa.31.129

3. Bogner, K. (2015). The effect of project funding on innovative performance: An agent-based simulation model. Hohenheim Discussion Papers in Business, Economics and Social Sciences. Retrieved from https://www.econstor.eu/bitstream/10419/121861/1/838724817. pdf

4. Carayol, N., \& Lanoe, M. (2018). The Impact and Design of ProjectBased Funding in Science: Lessons from the ANR Experience. Retrieved from: https://ideas.repec. org/p/hal/journl/hal-02274256. html

5. Clark, W., \& Gantt H. (1922). The Gantt chart, a working tool of management. New York: Ronald Press.

6. Europe 2020. European strategy for smart, sustainable and inclusive growth. Retrieved from https://ec.europa.eu/eu2020/pdf/
COMPLET\%20EN\%20BAR-

ROSO $\% 20 \% 20 \% 20007 \% 20-\% 20$ Europe\%202020\%20-\%20EN\%20 version.pdf

7. European Commission. (2016). CALL FOR PROPOSALS Clusters Go International. Retrieved from https://ec.europa.eu/research/participants/data/ref/other_eu_prog/ cosme/guide/call/cosme-call-proposal-cos-clusint-16301_en.pdf

8. European Commission. (n.d.). Horizon 2020 country profiles Retrieved from https://ec.europa. eu/info/research-and-innovation/ statistics/framework-programmefacts-and-figures/horizon2020-country-profiles_en

9. Fernandez-Blanco, A., VillanuevaBalsera, J., Rodriguez-Montequin, V., \& Moran-Palacios, H. (2020). Key Factors for Project Crowdfunding Success: An Empirical Study. MDPI, Open Access Journal, 12(2), 1-19. https://doi. org/10.3390/su12020599

10. Franssen, T., Scholten, W., Hessels, L. K., \& Rijcke, S. (2018). The Drawbacks of Project Funding for Epistemic Innovation: Comparing Institutional Affordances and Constraints of Different Types of Research Funding. Minerva, 56(1), 11-33. https://doi.org/10.1007/ s11024-017-9338-9

11. Harris, T. (2019). Grant Funding. Management for Profession- als, Start-up, (2nd ed., chapter

7) (pp. 85-98). https://doi. org/10.1007/978-3-319-94547-7_7

12. Horizon 2020. The Framework Programme for research and innovation (n.d.). Ramkova prohrama YeEs $z$ doslidzhen ta innovatsii (2014-2020) [Framework EU program for research and innovation]. (In Ukrainian). Retrieved from http://h2020.com. ua/wp-content/uploads/2015/11 /\%D0\%93\%D0\%BE\%D1\%80\%D 0\%B8\%D0\%B7\%D0\%BE\%D0\%B D\%D1\%82-2020-\%D0\%97\%D0\% B0\%D0\%B3\%D0\%B0\%D0\%BB\% D1\%8C\%D0\%BD\%D0\%B0-\%D1\%96\%D0\%BD\%D1\%84\%D0\%BE\%D1\%80\%D0\%BC\%D0\%B0\%D1 \%86\%D1\%96\%D1\%8F.pdf

13. Kozak, V. I. (2018). Zbir koshtiv yak instrument rozvytku terytorialnykh hromad v umovakh detsentralizatsii [Fundraising as a tool for the development of territorial communities under the conditions of decentralization]. Derzhavne upravlinnia ta mistseve samovriaduvannia - Public administration and local self-government, 3, 131141. (In Ukrainian). Retrieved from http://nbuv.gov.ua/UJRN/ dums_2018_3_18.

14. Krasnokutska, N. S., \& Osetrova T. O. (2018). Evoliutsiia rozvytku ta suchasni trendy v upravlinni 
proektamy [Evolution of development and current trends in project management]. Ekonomichnyi analiz-Economic analysis, 1(28), 236-242. (In Ukrainian).

15. Krupiak, I. Y., \& Krupiak, L. B. (2019). Osoblyvosti rozvytku fandraizynhu v Ukraini [Peculiarities of fundraising development in Ukraine. Efektyvna ekonomika - Effective economics, 10. (In Ukrainian). https:// doi.org/10.32702/2307-21052019.10 .53

16. Lavryk, O. L., \& Ponomarenko R. M. (2017). Finansuvannia proektiv ta yoho rol v suchasnii ekonomitsi Ukrainy [Project funding and its role in the modern economy of Ukraine]. Ekonomichnyi analiz Economic analysis, 4(27), 140-144. (In Ukrainian).

17. Lepori, B., Besselaar, P., Dinges, M., Meulen, B., Potì, B., Reale, E., Slipersaeter, S., \& Theves, J. (2007). Indicators for comparative analysis of public project funding: concepts, implementation and evaluation. Oxford Academic Research Evaluation, 16(4), 243-255. https://doi. org/10.3152/095820207X260252

18. Lepori, B., Reale, E., Spinello, A. O. (2018). Conceptualizing and measuring performance orientation of research funding systems. Oxford Academic Research Evaluation, 27(3), 171-183. https://doi. org/10.1093/reseval/rvy007

19. Lewandowska, L. (2013). Opportunities for funding innovation. Comparative Economic Research. Central and Eastern Europe, 16(4), 57-78. https://doi. org/10.2478/cer-2013-0028

20. Merzlyak, A. V., \& Skriabina, D. S (2018). Mekhanizm derzhavnoho rehuliuvannia zaluchennia inozemnykh priamykh investytsii v rehiony Ukrainy v systemi sitsio-ekonomichnoho zhyttia [Mechanism of state regulation of attracting foreign direct investment to the regions of Ukraine in the system of socio-economic life]. Pravo ta derzhavne upravlinnia - Law and public administration, 3(2), 81-89. (In Ukrainian).

21. Merzlyak, A., \& Vikhort, Yu. (2016). Prerequisites and pros- pects of public regulation of state and regions sustainable development. Baltic Journal of Economic Studies, 2(3), 83-89. https://doi. org/10.30525/2256-0742/2016-23-83-89

22. Nepelski, D., \& Piroli, G. (2018). Organizational diversity and innovation potential of EU-funded research projects. The Journal of Technology Transfer, 43, 615-639. https://doi.org/10.1007/s10961017-9624-6

23. Oharenko, V., \& Kozachenko, I. (2020). State regulation of the education sector under the conditions of decentralization. Baltic Journal of Economic Studies, 6(3), 99-106. https://doi.org/10.30525/22560742/2020-6-3-99-106

24. Rubel, O., \& Zhikhareva, A. (2018). The concept of the implementation of the performancebased research funding tool. Economic Innovations, 20(4(69)), 135-147. https://doi.org/10.31520/ ei.2018.20.4(69)

25. Schneider, F., Buser, T., Keller, R., Tribaldos, T., \& Rist, S. (2019). Research funding programmes aiming for societal transformations: Ten key stages. Science and Public Policy, 3(46), 463-478. https://doi. org/10.1093/scipol/scy074

26. Seymour T., \& Hussein S. (2014). The History of Project Management. International Journal of Management and Information Systems, 18(4), 233-240. https:// doi.org/10.19030/ijmis.v18i4.8820

27. Shenhar, A., \& Dvir, D. (2004). Project management evolution: past history and future research directions. Proceedings of the PMI Research Conference, 11-14 July 2004. London: Project Management Institute. Retrieved from https://www.pmi.org/learning/ library/project-management-evolution-research-directions- 8348

28. The Verkhovna Rada of Ukraine. (n.d.). Ukaz Prezydenta Ukrainy pro tsili staloho rozvytku Ukrainy na period do 2030 roku № 722/2019 vid 30.09.2019 [Decree of the President on the Sustainable Development Goals of Ukraine for the period up to 2030 No. 722/2019 dated September 30, 2019]. (In Ukrainian). Retrieved from https://zakon.rada.gov.ua/laws/ show/722/2019\#Text

29. The Verkhovna Rada of Ukraine. (n.d.a). Postanova pro zatverdzhennia poriadku formuvannia ta vykorystannia koshtiv Derzhavnoho innovatsiinoho fondu № 1242 vid 06.08.1998 [Decree of Ukraine on approval of the Procedure of formation and use of funds of the State Innovation Fund No 1242 dated August 6, 1998]. (In Ukrainian). Retrieved from https://zakon.rada. gov.ua/laws/show/ru/1242-98$\%$ D0\%BF/ed20000413/find?text= \%B2\%ED\%ED\%EE\%E2\%E0\%F6 \%B3\%E9\%ED\%E8\%E9+\%EF\%F0 \%EE\%E5\%EA\%F2\#Text

30. The Verkhovna Rada of Ukraine. (n.d.b). Law of Ukraine on Investment Activity No. 1560-XII as of September 18, 1991. Vidomosti Verkhovnoi Rady Ukrainy - Journal of the Varkhovna Rada of Ukraine, 47, 646. (In Ukrainian).

31. Tomareva-Patlahova, V. V., Boiko, O. V., Bondar, IU. A., \& Karpunina, M. S. (2020). Methodical approach to ensuring cluster and logistics development of the market. Economic Innovations, 22, 4(77) 29-38. https://doi.org/10.31520/ ei.2020.22.4(77).29-38

32. Turner, J. R. (2010). Evolution of project management research as evidenced by papers published in the International Journal of Project Management. International Journal of Project Management, 28(1), 1-6. https://doi.org/10.1016/j.ijproman.2009.10.009

33. United Nations. (n.d.). Tseli razvitiya tysiacheletiya: doklad za 2015 god [Millennium Development Goals: 2015 report]. (In Russian). Retrieved from https:// www.un.org/ru/millenniumgoals/ mdgreport2015.pdf

34. Vikhort, Yu. V. (2018). Upravlinnia finansovoiu ta investytsiinoiu pidtrymkoiu ekolohichnykh innovatsii yak odyn iz faktoriv yikh efektyvnoho vprovadzhennia v Ukraini [Management of financial and investment support of ecological innovations as one of the factors of their effective implementation in Ukraine]. 
Efektyvna ekonomika - Effective economics, 10. (In Ukrainian). https://doi.org/10.32702/23072105-2018.10.51

35. Wahjono, S. I., Marina, A., Fikry, M., \& Anggraeni. (2015). Innovative funding solution for special projects: Crowdfunding. Journal of Economics, Business, and Accountancy Ventura, 18(1) 65-74. https://doi.org/10.14414/ jebav.15.1801006
36. Wozniak, K., \& Wawak, S. (2020). Evolution of project management studies in the XXI century. International Journal of Managing Projects in Business, 13(4), 867-888. https://doi.org/10.1108/ IJMPB-01-2020-0002

37. Zacharewicz, T., Lepori, B., Reale, E., \& Jonkers, K. (2019). Performance-based research funding in EU Member States: a comparative assessment. Oxford Academic,
Science and Public Policy, 46(1), 105-115. https://doi.org/10.1093/ scipol/scy041

38. Zinilli, A. (2016). Competitive project funding and dynamic complex networks: evidence from Projects of National Interest (PRIN). Scientometrics, 108(2), 633-652. https://doi.org/10.1007/ s11192-016-1976-4 